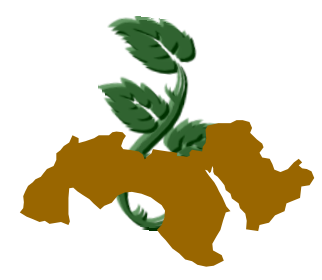

\title{
A REVISION OF THE GENUS Triticum L. IN EGYPT
}

\author{
Hafeez R. Habeeb ${ }^{1}$ \\ 1- Flora and Phytotaxonomy Researches Department, Horticultural Research Institute, \\ Agricultural Research Center, Dokki, Giza, Egypt
}

Keywords: Triticum, Taxonomy, Egypt

\section{ABSTRACT}

This study was conducted to revise the taxonomic identity and clarify specific relationships among the studied Triticum species in Egypt. The studied species included; T. dicoccum (Schrank) Schubl.; T. dicoccoides (Koren ex Asch. \& Graebn.) Aaron Sohn. T. tugidum L.; T. durum Desf.; T. pyramidale (Delile ex Schult.) Percival and $T$. aestivum L. Moreover, the wild Emmer Wheat $T$. dicoccoides (Koren ex Asch. \& Graebn.) Aaron Sohn was recently found in Egypt as a new record. The genus Triticum L. includes 14 species, all of them are cultivated for food except the wild Emmer.

\section{INTRODUCTION}

Gramineae is one of the largest families of flowering plants. It includes about 620 genera and 10,000 species Clayton \& Renvoize, (1986). In the Egyptian flora, Gramineae is represented by 93 genera and 224 species (Täckholm, 1974), while Boulos, (2009) records 110 genera and 284 species. El-Khanagry (2004) added 6 species as new taxa to the flora of Egypt. The genus Triticum includes 15 species worldwide according to Huller (1995). Townsend et al (1968); Davis et al (1985); Naomi (1986) and Boulos (2005) classified and described this genus. All species of Triticum are cultivated except the wild Emmer Wheat T. dicoccoides.

\section{MATERIAL AND METHOD}

The specimens were collected by El-Khanagry from Egypt and are kept in the Herbarium of Flora and Phytotaxonomy Researches Department
(CAIM), Egypt. The duplicates of this specimen were identified by T.A. Cope at Royal Botanical Garden, Kew, England. The key and the descriptions of the genus and the species are adopted after Boulos, (2005).

\section{RESULTS AND DISCUSSION}

All species of the genus Triticum L. are annuals; raceme linear or oblong, bearing single spikelets on a fragile rhachis (tardily fragile or tough in cultivated species); spikelets several-flowered (rarely only one of the florets fertile); glumes oblong to ovate, shorter or rarely longer than the adjacent lemmas, coriaceous, 5- to 11-nerved, asymmetrically 1- to 2-keeled (but sometimes becoming rounded below as the grain expand), obtuse, truncate or toothed at the tip, the lateral nerves diverging into the teeth, mucronate or awned; lemmas rounded on the back or keeled near the tip similar to that of the glumes. Distribution: East Mediterranean region to Iran.

\section{Triticum dicoccoides (Koern. ex Asch. \& Groebn.) Aaron Sohn}

Culms erect $20-150 \mathrm{~cm}$., branched at base. Lower internodes hollow; the upper ones solid, glabrous to pubescent. Sheath hairy and ciliated, ligule 1-2 mm., scarius, mouth hairy. Blade linear, acute, glabrous to nearly pubescent. Racemes awned compacted up to $10 \mathrm{~cm}$. long. Rachis hairy at nodes, disarticulated at maturity, spikelet 1-2 flowered; glumes rigid awnless up to $15 \mathrm{~mm}$. long with one sharp tooth up to $5 \mathrm{~mm}$ long and leathery ciliated keel; lemma lanceolate-acute up to $11 \mathrm{~mm}$. long with long awns $10-20 \mathrm{~cm}$. long; palea hairy; caryopsis adherent; $2 n=28$ (plate 1 ).

It is distributed through Western Asia, Southern and Eastern Europe. The species was collected 
from Horticulture at Research Station, Faculty of Agriculture, Cairo University, Giza, Experimental plot of faba bean, 26.4.2001, and beside irrigation canals, 23.5.2002.

\section{Triticum dicoccum (Schrank) Schubl.}

Synonym: T. spelta L. var. dicoccum Schrank

Culms to $1 \mathrm{~m}$., glabrous or pubescent at the nodes, thick-walled or solid throughout; leaf-blades scaberulous; racemes $3-10 \mathrm{~cm}$., laterally firmly compressed; rhachis fragile, disarticulating at the base of the internodes, these $3 \mathrm{~mm}$., glabrous or shortly ciliate at the nodes and on the margins; spikelets 3(4)-flowered, only the 2 lowermost fertile; glumes (0.6)0.7-1 cm., broadly ovate, coriaceous, with a single prominent keel running into an apical tooth; awn scabrid, to $15 \mathrm{~cm}$.; grain hulled, with flinty or mealy endosperm; $2 n=28$.

\section{Triticum turgidum $\mathrm{L}$.}

Synonym: T. compositum L.

Culms to $1.7 \mathrm{~m}$, smooth and glabrous throughout, thick-walled and \pm solid; leaf-blades velutinous (but this rubbing off with age); raceme nodding, 4.5-7 cm., ovate- cylindrical, sometimes branched below; rhachis tough, densely ciliate, the internodes (2.5)3.5-4 mm.; spikelets 5 to 7-flowered, the lowermost 2-5 florets fertile, glumes broadly ovate, $0.8-1 \mathrm{~cm}$., coriaceous, glabrous, puberulent or velutinous, keeled throughout with 2 keels, one of them prominent, ciliolate, terminating in a 1-2 $\mathrm{mm}$. tooth, the other less developed; fertile lemma $1-1.3(1.4) \mathrm{cm}$., glabrous or villous towards the margins; awn scabrid throughout, $8-18 \mathrm{~cm}$.; grain naked, with mealy endosperm and without a dorsal hump or ridge, $2 n=28$.

\section{Triticum durum Desf.}

Culms to 1.4 m., smooth and glabrous throughout, thick-walled, sometimes solid; leafblades glabrous; raceme $3-8 \mathrm{~cm}$., erect, dense, laterally compressed; rhachis tough, densely ciliate, the internodes 3-4 mm. long; spikelets 5(7)flowered, only the lowermost (2)3-4 florets fertile; glumes $0.8-1(1.2) \mathrm{cm}$., broadly ovate, coriaceous, glabrous or pubescent, keeled throughout with 2 keels, one of them prominent, scaberulous, terminatingin a 2-3 $\mathrm{mm}$. long apical tooth, the other weakly developed; fertile lemma 1-1.2 cm., glabrous; awn (5.5)10-15 cm, smooth below, scabrid above; grain naked with flinty endosperm and with a prominent dorsal hump or ridge; $2 \mathrm{n}=28$.

\section{Triticum pyramidale (Delile ex Schult.) Percival}

Synonym: T. sativum Lam. var. pyramidale Delile ex Schult.

Culms to $1 \mathrm{~m}$., glabrous, thick-walled, sometimes solid; leaf-blades pubescent when young; raceme 4.5-6 cm., pyramidal, broad below, tapering above, dense; rhachis tough, ciliate, the internodes 2.5-3 mm.; spikelets 4-to 5-flowered, the lowermost 3-4 florets fertile; glumes $0.8-1 \mathrm{~cm}$., broadly ovate, coriaceous, glabrous, or pubescent, keeled throughout with 2 keeles, one of them prominent, scabrid, terminating in a $0.5-1 \mathrm{~mm}$. apical tooth, the other weakly developed; fertile lemma 1-1.2 cm., glabrous; awn 9-17 cm., scabrid throughout; grain naked with mealy endosperm and a prominent dorsal hump or ridge; $2 n=28$.

\section{Triticum aestivum L.}

Synonyms: T. hybernum L.; T. sativum Lam.; $T$. vulgare Vill.

Culms to 1.4 m., smooth and glabrous throughout or faintly puberulent at the nodes, thinwalled and hollow; leaf-blades scaberulous, puberulent or glabrous; raceme (1.5)5-10 cm., erect, lax to dense; rhachis tough, glabrous or ciliate, the internodes (3)4-8 mm.; spikelets 3-to 9-flowered, usually only the (2)3 lowermost florets fertile; glumes $0.6-1(1.1) \mathrm{cm}$., broadly ovate, coriaceous, glabrous, pubescent or villous, keeled in the upper part only, the single keel terminating in a $2-3 \mathrm{~mm}$. apical tooth or a $0.4-1 \mathrm{~cm}$. scabrid awn; fertile lemma (1)1.2-1.5 cm.; awn 4-10(12) cm., scabrid throughout, or lemma awnless; grain naked with mealy (to flinty) endosperm, smoothly dorsally curved without a hump or ridge; $2 n=42$.

Triticum species treated in this work are differentiated as follows. For $T$. dicoccoides: Spike compressed $4-10 \times 0.7-1.5 \mathrm{~cm}$; rachis fragile ,internodes $3-5 \mathrm{~mm}$., ciliated margin with tuft hairy up to $5 \mathrm{~mm}$. at each node. Spikelets $12-15 \mathrm{~mm}$; compressed and appressed to rachis with (1)-2(3) flowerest. Glume 10-15 mm. with 2keel one from the mid vein produced as a sharp tooth up to $2 \mathrm{~mm}$. 


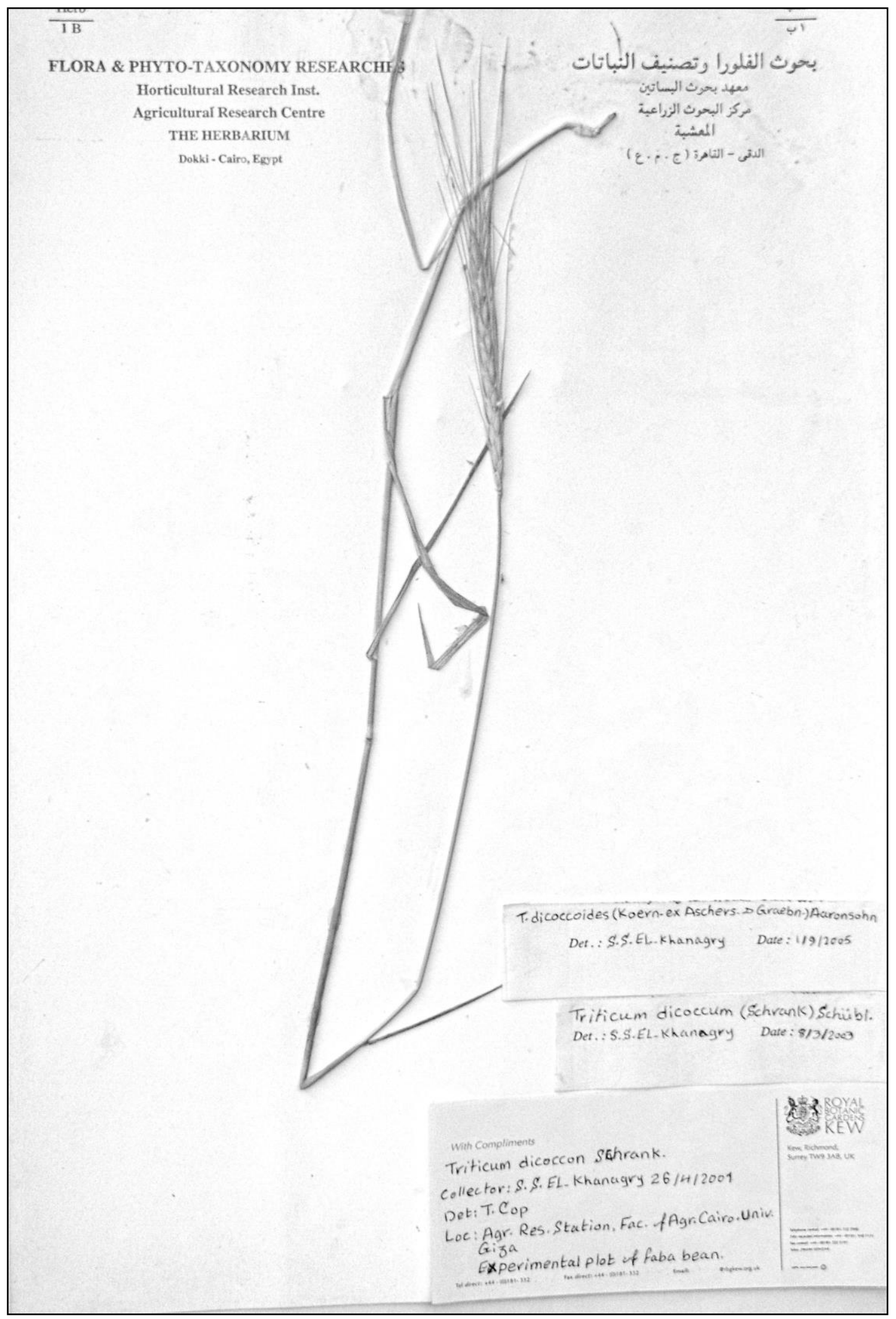

Photo 1: Triticum dicoccoides

Arab Univ. J. Agric. Sci., 21(1), 2013 
Fertile lemma $10-15 \mathrm{~mm}$. with awn $15-20 \mathrm{~cm}$. Caryopsis $9-11 \times 1.5-2.5 \mathrm{~mm}$. adherent to lemma and palea. $2 \mathrm{n}=28$ Townsend et al (1968); Davis et al (1985) and Naomi, (1986).

For $T$. dicoccon: spike $3-10 \times 1-1.3 \mathrm{~cm}$., laterally compressed. Rachis fragile, glabrous, disarticulating above spikelets 3-4 flowered. Glume 6-10 mm., coriaceous, with single prominent keel ,lemma with awn up to $15 \mathrm{~cm}$., caryopsis free $2 \mathrm{n}=28$ Davis et al (1985) and Tutin et al (1980).

On the other hand, in T. dicoccum: Spike (raceme) $3-10 \mathrm{~cm}$., rachi fragile, glabrous or shortly ciliate at the nodes and on the margins. Spiklet 3-4 flowered, only the two lower most fertile. Glumes 0.6-1 cm., with one sharp-tooth keel, lemma of $9 \times 4$ $\mathrm{mm}$. with awn up to $15 \mathrm{~cm}$.; caryopsis $7-9 \times 2.8-3.4$ $\mathrm{mm}$. free $2 \mathrm{n}=28$ (Townsend et al 1968). $T$. monococcum was described by Davis et al (1985) as follows: spike erect $2.5-4 \mathrm{~cm}$., strongly; rachis tough not disarticulating at maturity, glabrous. Spikelets 2-3 flowerest usually one fertile. Glume 6-8 mm., coriaceous with two keels. Fertile lemma 8-10 $\mathrm{mm}$. with awn scarbid awn $3-8 \mathrm{~cm}$. Palea splitting to base at maturity. Grain free $2 n=28$.

Finally, El-Khanagry (2004) described T. dicoccum as follows: spike awned compacted, up to 10 $\mathrm{cm}$. long., rachis hairy at nodes, disarticulated at maturity. Spikelet with two floret. Glumes awnless, with one sharp tooth up to $2 \mathrm{~mm}$. long and leathery ciliated keel; lemma with long awn 10-15 cm. long. The specimen was identified by $\mathrm{T}$. Cop as $T$. dicoccon, then El-Khanagry renamed and published it as $T$. dicoccum.

The investigator found some characters not registered such as: spikelets compact to rachis, nodes with tuft hairy up to $5 \mathrm{~mm}$. at the tip, caryopsis $10-2.2 \mathrm{~mm}$., adherent to lemma and palea. The revision of the specimens was compared with the description of species Triticum Townsend et al (1968); Davis et al (1985); Naomi, (1986); ElKhanagry, (2004) and Boulos, (2005). Also, this species is a new record to the flora of Egypt. It was introduced to Egypt for breeding purposes and was neutralized as a weed. The investigator proposes the following key to identify Triticum species in Egypt as follows:
1. Raceme-rhachis fragile, disarticulating at maturity ......................................... 2

+ Raceme-rhachis tough, not disarticulating

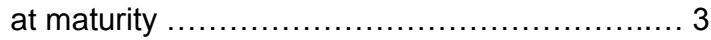

2. Raceme flattened .............. 1. T.dicoccoides + Raceme terete .................... 2. T. dicoccum

3. Glumes keeled only towards the tip $\ldots \ldots \ldots \ldots .6$

T. aestivum

+ Glumes keeled from base to tip .................4

4. Raceme pyramidal ............. 5. T.pyramidal

+ Raceme oblong $\ldots \ldots \ldots \ldots \ldots \ldots \ldots \ldots \ldots \ldots \ldots$

5. Leaves velutinous ............... 3. T. turgidum

+ Leaves glabrous ................... 4. T. durum

\section{REFERENCES}

Boulos L., 2005. Flora of Egypt. Vol. IV, Al Hadara Publ., Cairo, Egypt.

Boulos L., 2009. Flora of Egypt Checklist. Al Hadara Publ., Cairo, Egypt.

Clayton W. and Renvoize S.A. 1986. Genera Gramianum: Grasses of the World, Kew Bulletin, Additional series. XIII, London.

El-Khanagry S.S.G., 2004. New Records of Some Monocotyledonous Taxa to the Flora of Egypt, $1^{\text {st }}$ Conf. on Strategy of Egyptian Herbaria, Egypt.

Huller 1995. Wheats: Promoting the Conservation and Used Underutilized and Neglected Crops, $1^{\text {st }}$ Workshop on Hulled Wheat, Castevecction Pascoli, Toscany, Italy.

Davis P.T., Mill R.R. and Kit Tan, 1985. Flora of Turkey and East Aegean Islands, vol. 9, Edinburgh University.

Melchoir H. 1964. A. Engler's Syllabus der Pflanzenfamilien, $12^{\text {th }}$ edition, Gebruder Borntaeger, Berlin.

Naomi F-Dothan, 1986. Flora Palaestina, the Israel Academy of Sciences and Humanities, Jerusalem.

Täckholm, V. 1974. Student Flora of Egypt. $2^{\text {nd }}$ ed. Cairo University.

Towsend, C.C., Guset E. and Al-Raw A., 1968. Flora of Iraq, Ministry Agriculture, Baghdad, Iraq.

Tutin E.G., Heywood V., Burges N. Moore D., Valentine D., Walters S. and Weebb D. 1980. Flora Europaea, Cambridge University Press, Cambridge, London. 